\title{
42. INVESTIGATION OF SEDIMENT MICROSTRUCTURE AT SITES 646 AND 647, OCEAN DRILLING PROGRAM LEG 105 1
}

\author{
Kathleen A. Dadey²
}

\begin{abstract}
Possible genetic relationships between syn- and post-depositional processes and sediment microstructure were investigated. Samples from cores at Sites 646 and 647 of Ocean Drilling Program (ODP) Leg 105 included examples of bottom current deposition (contourites), turbidity current deposition, consolidation, and diagenesis.

Examination of nearly 200 micrographs of 14 samples from Site 646 and 13 samples from Site 647 leads to the conclusion that sedimentation processes do not appear to have an obvious influence on fabric. The effects of post-depositional processes, such as bioturbation, coring disturbance, and even remolding, appear to be less significant than one might expect as a result of the relatively coarse grain size of the sediments studied.

Consolidation resulting from increased overburden stress results in increased particle alignment and compression of fabric elements with depth. The transition from open, random fabric in shallow samples to preferred orientation at depth represents the only change in these sediments that can be ascribed directly to a specific depositional or post-depositional process. Mineralogical variations, owing to changes in weathering processes and growth of authigenic/diagenetic minerals, also have a pronounced effect on sediment fabric.
\end{abstract}

\section{BACKGROUND AND OBJECTIVES}

A number of different methods at different scales have been used to identify contourite (drift) deposits in the world ocean. On the megascopic scale of seismic-reflection profiling, drift deposits are thicker than adjacent sediment cover. Their internal reflectors are weak and do not conform to the underlying topography. Bedforms, such as mud waves, frequently have been observed on the surface of these deposits (McCave and Tucholke, 1986).

Macroscopic examination of sediment cores also yields criteria for recognizing contourites. Chough and Hesse (1985) reported that bioturbation is a ubiquitous and diagnostic characteristic of contourites and may be used to distinguish drift deposits from turbidites. Stow and Piper (1984) identified contourite facies on the basis of irregular vertical sequences of facies types having both positive and negative grading. Stow and Piper agreed that bioturbation is common but that "ghosts" of primary structures originally generated by depositional processes remain. In addition, Shor et al. (1984) employed anistropy of magnetic susceptibility (AMS) to identify contourite deposits by examining the preferential alignment of magnetic minerals within a sediment. Grain alignment parallel to the current direction distinguishes contourites from downslope transport deposits.

The main purpose of this investigation is to explore possible genetic relationships between syn- and post-depositional processes and sediment fabric on a microscale. Special attention is paid to the potential of microstructure for identification of contourite and turbidite deposits.

The sediments examined are from two sites drilled during Leg 105 . Holes $646 \mathrm{~A}$ and $646 \mathrm{~B}$ were drilled on a flank of the Eirik Ridge, a drift deposit off the southwest coast of Greenland (Fig. 1). Turbidite layers generated by spillover from the North Atlantic Mid-Ocean Channel (NAMOC) and ice-rafted material also are present in these holes. Holes 647A and 647B are located just south of Gloria Drift in the southern Labrador

\footnotetext{
${ }^{1}$ Srivastava, S. P., Arthur, M., Clement, B., et al., 1989. Proc. ODP, Sci. Results, 105: College Station, TX (Ocean Drilling Program).

2 Graduate School of Oceanography, University of Rhode Island, Narragan-
}

Sea (Fig. 1). Younger sediments at Site 647 are dominated by ice-rafting. A number of turbidite layers were also observed (Srivastava, Arthur, et al., 1987). Hemipelagic sediments were recovered at both sites.

The microstructure of sediments from these two sites is described and considered in light of the operating depositional and post-depositional processes. Processes believed to have an important influence on fabric include transport by bottom currents and turbidity currents, post-depositional reworking (physical and biological), consolidation, diagenesis, and lithification.

\section{METHODOLOGY}

Fourteen samples from Site 646 and 13 samples from Site 647 were examined (Table 1). Specimens from all lithologic units were included. Each was assigned a random number as identification to reduce the possibility of bias arising from knowledge of a sample's depth, location, or lithology.

Samples were obtained on board the Resolution in $1-\mathrm{cm}^{3}$ plexiglass cubes that were coated with parafin and stored at $2^{\circ} \mathrm{C}$ to decrease the possibility of evaporation and disruption to the microstructure. Two basic preparation techniques were employed. Samples having water contents greater than approximately $70 \%$ (dry weight) were dried using the critical point drying (CPD) method described by Bennett et al. (1977). Pore fluid was replaced with acetone of gradually increasing concentrations. The acetone subsequently was replaced with liquid carbon dioxide in the CPD apparatus. This carbon dioxide then was brought to its critical point, and the resulting carbon dioxide gas was removed with virtually no alteration to the fabric. For a complete and detailed description of the preparation procedures, refer to Dadey (1983).

Freeze-drying was used on samples having water contents of less than about $60 \%$. Several authors have expressed misgivings regarding the effects of ice crystal growth during freezing on sediment microstructure (e.g., Tovey and Yan, 1973). We investigated this possibility by preparing the sample from a depth of 7.4 meters below seafloor (mbsf) in Hole $646 \mathrm{~A}$ (with a water content of $102 \%$ ) using both methods. No discernible differences in the basic microstructure were observed. Furthermore, a semiquantitative investigation of pore size and particle alignment showed that minimal differences exist in samples prepared by either method. This observation suggests that freeze-drying causes an insignificant degree of disturbance in these sediments and is suitable for the samples having lower water contents.

Dried samples were fractured to expose fresh surfaces perpendicular to bedding and coated with carbon and gold palladium to ensure electrical conductivity. Both a Cambridge Instruments Scanning Electron Microscope (SEM) and a JEOL Scanning Transmission Electron Micro- 


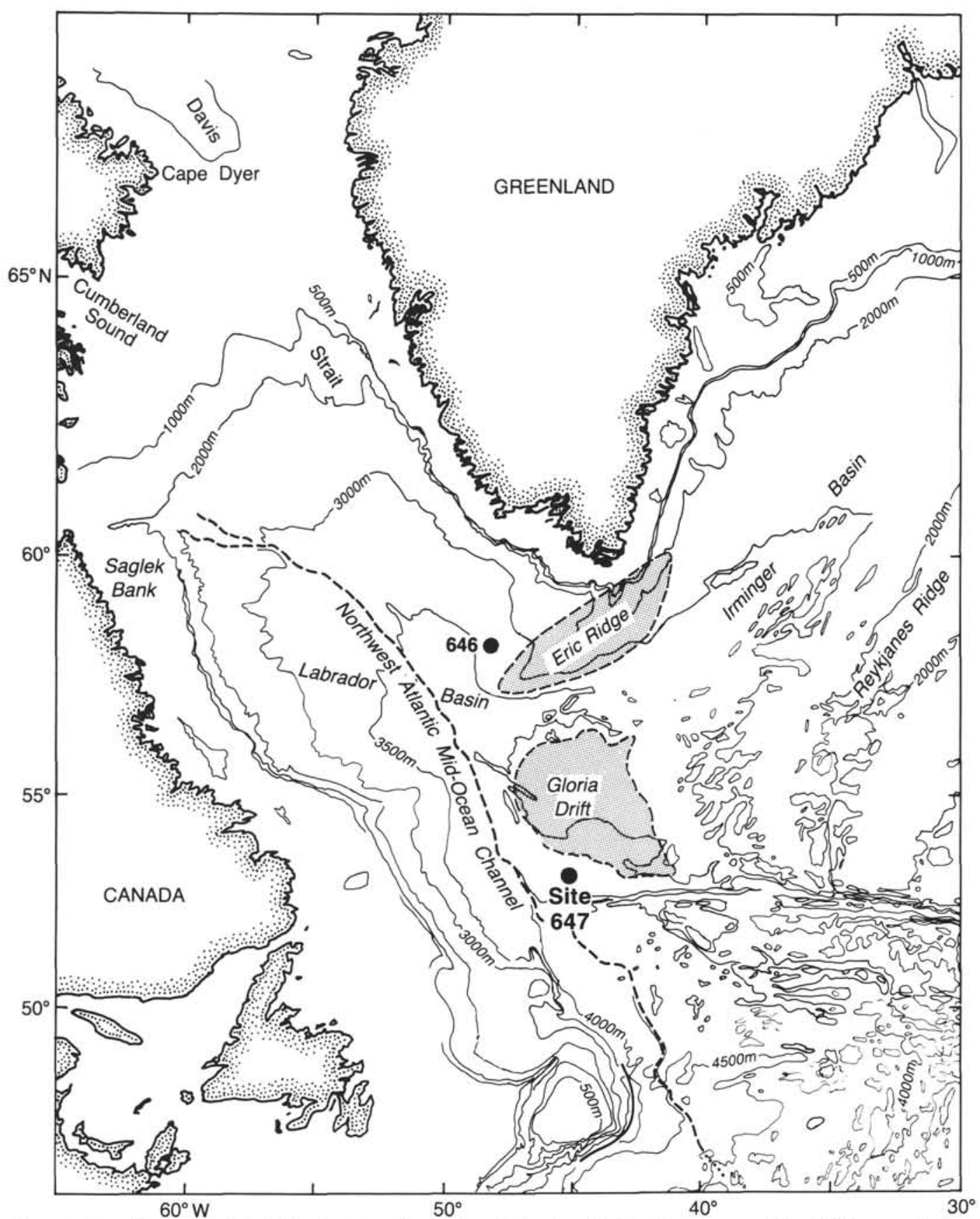

Figure 1. Location map of the Labrador Sea. Sites 646 and 647, described in this paper, are identified, as are drift deposits at Eirik Ridge and Gloria Drift.

scope (STEM) were used for this study. All figures reproduced here were generated by the STEM in scanning mode. Magnifications ranged from approximately $2000 \mathrm{X}$ to more than $10,000 \mathrm{X}$. At least three photomicrographs were taken of microstructure chosen as representative in each sample. Unusual features were investigated separately. Nearly $200 \mathrm{mi}-$ crographs were examined.

\section{RESULTS}

\section{Site 647}

On the basis of microstructure, the sediments from Site 647 analyzed here can be divided into three basic categories. These categories, their descriptions, and their depth ranges are summarized in Figure 2. In the shallow Zone A, the fabric is domi- nated by silt- and clay-sized plates having regular, well-defined outlines. Based on the limited data of Nielsen et al. (this volume), these plates are believed to be primarily detrital grains of illite, kaolinite, and chlorite. Generally, silt grains are supported in a clay-sized matrix composed primarily of particles displaying edge-to-edge (E-E) and edge-to-face (E-F) contacts. Much of the matrix consists of single-plate particle arrangements and large, open flocs (Fig. 3). The result is an open microstructure resembling the classic "cardhouse" fabric of Lambe (1953) and others. The only exception is the sample from $33.0 \mathrm{mbsf}$, which has the highest silt concentration in this hole (Srivastava, Arthur, et al., 1987). This sample exhibits domains of particles (terminology of Bennett et al., 1981) having face-to-face (F-F) contacts and is essentially grain-supported. 
Table 1. Samples used in microstructure investigation.

\begin{tabular}{|c|c|c|c|c|c|}
\hline Sample & $\begin{array}{l}\text { Depth } \\
\text { (mbsf) }\end{array}$ & $\begin{array}{c}\text { Water } \\
\text { content } \\
(\%)\end{array}$ & $\begin{array}{l}\text { Porosity } \\
(\%)\end{array}$ & $\begin{array}{l}\text { Preparation } \\
\text { procedure* }\end{array}$ & Comments \\
\hline \multicolumn{6}{|l|}{$105-646 \mathrm{~A}-$} \\
\hline $1 \mathrm{H}-2$ & 2.3 & 136 & 76 & CPD & \\
\hline $2 \mathrm{H}-2$ & 7.4 & 102 & 75 & ${ }^{*} \mathrm{FD}$ and $\mathrm{CPD}$ & \\
\hline $3 \mathrm{H}-2$ & 19.1 & 110 & 78 & CPD & \\
\hline $6 \mathrm{H}-3$ & 49.4 & 69 & 67 & CPD & Probably flow-in. \\
\hline $8 \mathrm{H}-3$ & 69.1 & 98 & 74 & CPD & \\
\hline $10 \mathrm{H}-5$ & 91.2 & 75 & 70 & CPD & $\begin{array}{l}\text { In calcareous } \\
\text { turbidite layer. }\end{array}$ \\
\hline $11 \mathrm{H}-3$ & 97.6 & 76 & 71 & CPD & In laminated layer. \\
\hline \multicolumn{6}{|l|}{ 105-646B- } \\
\hline $14 \mathrm{H}-5$ & 127.5 & 58 & 64 & FD & \\
\hline $18 X-3$ & 162.9 & 66 & 67 & FD & Remolded. \\
\hline $20 X-3$ & 182.3 & 70 & 67 & CPD & \\
\hline $26 \mathrm{X}-4$ & 241.4 & 58 & 63 & FD & Biscuits present. \\
\hline $35 X-2$ & 326.3 & 54 & 60 & FD & Biscuits present. \\
\hline $50 X-1$ & 469.5 & 30 & 30 & FD & Biscuits present. \\
\hline $72 X-1$ & 680.1 & 26 & 43 & FD & Biscuits present. \\
\hline \multicolumn{6}{|l|}{ 105-647B- } \\
\hline $1 \mathrm{H}-3$ & 3.4 & 91 & 72 & CPD & $\begin{array}{l}\text { Slight coring } \\
\text { disturbance. }\end{array}$ \\
\hline $2 \mathrm{H}-1$ & 6.8 & 104 & 74 & CPD & \\
\hline $3 \mathrm{H}-5$ & 23.3 & 69 & 65 & CPD & \\
\hline $4 \mathrm{H}-5$ & 33.0 & 61 & 63 & FD & \\
\hline $8 \mathrm{H}-5$ & 71.2 & 58 & 62 & FD & \\
\hline $11 \mathrm{H}-2$ & 95.3 & 46 & 55 & FD & $\begin{array}{l}\text { Moderate coring } \\
\text { disturbance. }\end{array}$ \\
\hline \multicolumn{6}{|l|}{$105-647 \mathrm{~A}-$} \\
\hline $13 \mathrm{R}-5$ & 123.1 & 194 & 87 & CPD & $\begin{array}{l}\text { Coarse-grained layer, } \\
\text { high } \mathrm{SiO}_{2} .\end{array}$ \\
\hline 15R-1 & 136.4 & 202 & 86 & CPD & High $\mathrm{SiO}_{2}$ content. \\
\hline 21R-1 & 194.1 & 136 & 80 & CPD & $\mathrm{High} \mathrm{SiO}_{2}$ content. \\
\hline 25R-5 & 238.9 & 120 & 84 & FD & High $\mathrm{SiO}_{2}$ content. \\
\hline $35 \mathrm{R}-2$ & 330.1 & 43 & 56 & FD & \\
\hline 47R-4 & 449.2 & 37 & 52 & FD & Biscuits. \\
\hline $62 \mathrm{R}-2$ & 599.8 & 25 & 43 & FD & $\begin{array}{l}\text { Biscuits; in dusty } \\
\text { red layer. }\end{array}$ \\
\hline
\end{tabular}

- $\mathrm{CPD}=$ Critical point drying; $\mathrm{FD}=$ Freeze drying.

concentration in this hole (Srivastava, Arthur, et al., 1987). This sample exhibits domains of particles (terminology of Bennett et al., 1981) having face-to-face (F-F) contacts and is essentially grain-supported.

Sediments from Zone B display significantly different microstructure. Components appear more flaky, often with poorly defined perimeters. Particle contacts are generally E-E or E-F, or only partially visible (Fig. 4). Diatom and cocolith fragments are abundant, and pyrite crystals were observed in two of the five samples from this microstructure zone. Also noteworthy is the presence of pore-bridging, threadlike, intertwined fibers (Fig. 5).

The two deepest samples examined (450 and $600 \mathrm{mbsf}$ ) have another distinct microstructure (Zone C; Fig. 2). Many F-F packets are visible, and the fabric displays greater alignment and smaller, less numerous voids than shallower specimens. Particles in some areas appear distorted, their edges curled up perpendicular to the particle face (Fig. 6).

Measuring void dimensions on enlargements of micrographs of shallow and deep samples semiquantitatively confirm the change in fabric with depth. The average length-(parallel to bedding) to-height (perpendicular to bedding) ratio of voids in the shallow sample is 0.66 , whereas that of the deep sample is 3.51 . Moreover, none of the height measurements in the deep sample exceed $2.6 \mu \mathrm{m}$. In contrast, all void heights in the shallow sample were greater than $2.6 \mu \mathrm{m}$. This is in general agreement with Bennett et al. (1981), who discussed a similar change in void shape in Mississippi Delta sediments above and below approximately $100 \mathrm{~m}$.

\section{Site 646}

The most definitive changes in microstructure at Site 646 appear to correlate most closely with the downhole decrease in water content and the porosity caused by increasing consolidation. Instead of the relatively distinct zones observed at Site 647, the sediment microstructure at Site 646 exhibits gradational changes with depth. As a result, the boundaries of the zones delineated in Figure 7 are somewhat arbitrary.

Shallow samples in Zone X typically display an open, matrix-supported fabric with abundant E-E and E-F contacts and large void spaces. In general, the nonbiogenic particles are visually similar to those in microstructure Zone A of Site 647 and have regular, well-defined outlines. Particle arrangements also resemble those of Zone A in Hole 647B, with abundant singleplate chains and flocs forming a cardhouselike structure (Fig. 8).

Microstructure Zone $\mathrm{Y}$ is characterized by increased parallel alignment and the development of domains of particles displaying primarily F-F contacts (Fig. 9). A slight reversion to a more open microstructure at $\mathbf{1 8 2 . 3}$ mbsf can be attributed to an increase in porosity.

In Zone Z, fabric begins to be dominated by large, compressed domains, composed of smaller particles in F-F and stepped F-F alignment (Fig. 10). Single plates and chains of plates are rare. The upper limit of this zone corresponds fairly closely with the boundary between soft and lithified sediments (Srivastava, Arthur, et al., 1987), which lends further support to the theory that the degree of consolidation plays a major role in determining the sediment microstructure at this site. Distortion of clay plates (Fig. 11), similar to that described in Zone $\mathrm{C}$ of Site 647 , is consistent with high overburden stresses, low porosity, and an advanced degree of consolidation (see "Discussion" section, this chapter). Nevertheless, regions of relatively open, random fabric remain, even at $680 \mathrm{mbsf}$ (Fig. 10).

Measurements of pore spaces on micrograph enlargements of representative shallow and deep samples from Site 646 yielded results similar to those of Site 647 specimens. The average lengthto-height ratios are 0.64 and 3.26 for the shallow and deep samples, respectively. Void heights in the shallow sample are greater than $3.0 \mu \mathrm{m}$, whereas all but one of those in the deep sample are less than $2.2 \mu \mathrm{m}$.

\section{DISCUSSION}

The most dramatic change in microstructure at Site 647 occurs between Zones A and B and corresponds to lithologic Units I and II (Fig. 2). The well-defined, regular plates of the shallow zone replace the fleecy, flaky particles that dominate deeper layers.

The microstructure at this site does appear to be related to depositional environment, but only indirectly. Actually, microstructure is controlled primarily by sediment lithology and mineralogy, which are in turn influenced by the mode of deposition.

The majority of material in Unit I (Zone A) is derived from terrigenous sources, and much was transported to the site by icebergs. Consequently, physical weathering processes are responsible for most of the components, and the mineralogy is dominated by detrital minerals. The data of Nielsen et al. (this volume), although limited for Unit I, support this hypothesis with a trend of increasing illite and decreasing smectite in the few samples tested in the upper unit.

On the other hand, Zone B is characterized by authigenic minerals, mainly nontronitic smectite (Nielsen et al., this volume). This zone is composed of a number of condensed sequences of hemipelagic origin and probably includes periods of 


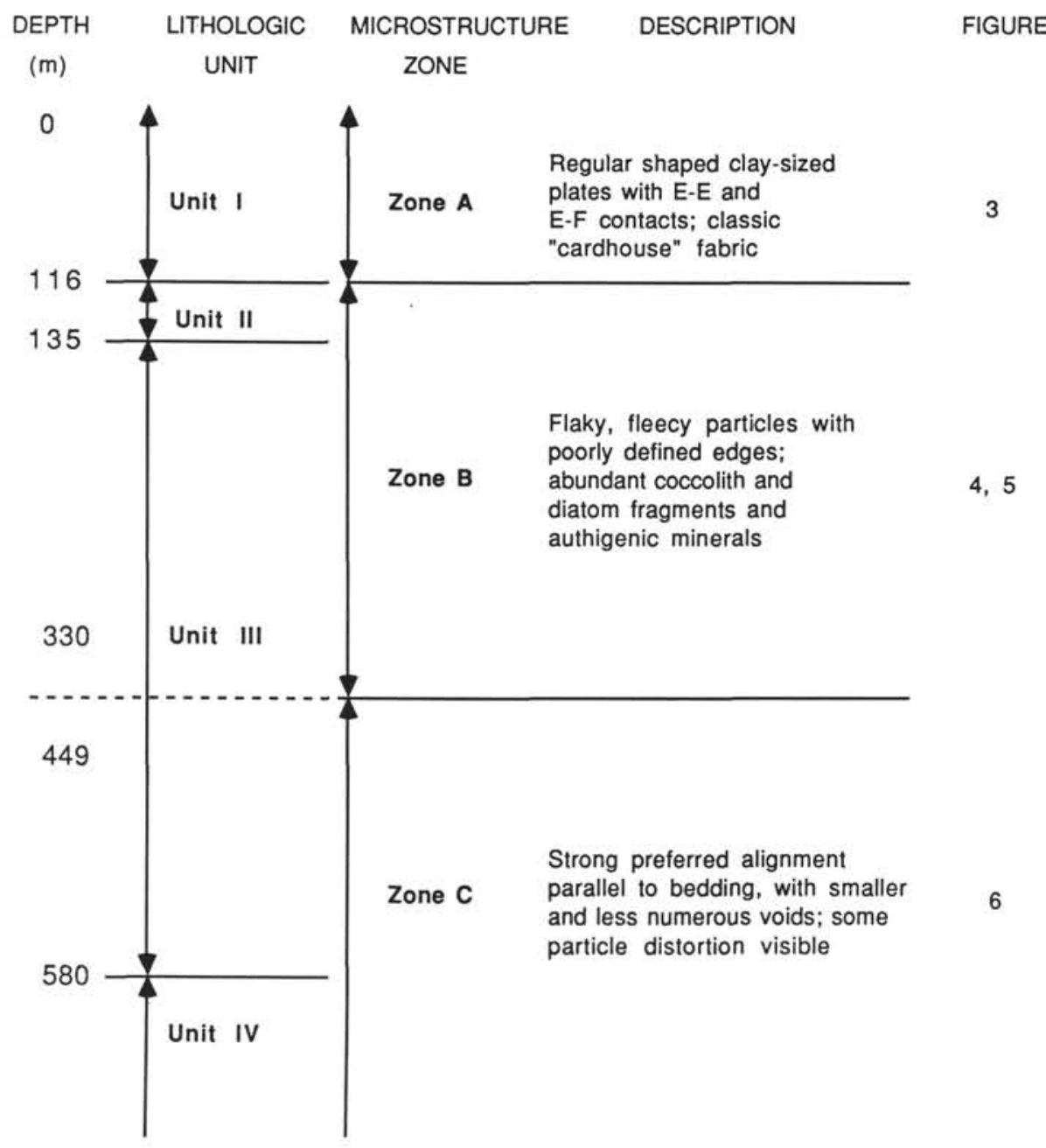

Figure 2. Site $647-$ microstructure zones and lithologic units.

nondeposition (Srivastava, Arthur, et al., 1987). In-situ formation of smectite and other minerals is volumetrically important in these strata. The mineralogy is reflected in the microstructure by the occurrence of pyrite and especially by the predominance of fleecy, flaky smectite particles.

Accompanying the change in the type of structural unit observed (i.e., the type of clay particle) is a change in the kind of particle associations. Because illite and chlorite occur as thin plates, they tend to form random, open-particle arrangements (Bennett et al., 1977, 1981), whereas fabrics composed of smectite are more often domain-dominated (Bohlke and Bennett, 1980).

The second significant microstructure change at Site 647, which occurs below approximately $450 \mathrm{mbsf}$ (Fig. 2), can be attributed primarily to the effects of consolidation and lithification. Increased parallel alignment and smaller and less numerous voids are accompanied by diagenesis, such as pore-bridging authigenic minerals. Note the presence of authigenic/diagenetic minerals at depths less than the $2 \mathrm{~km}$ generally cited as the point at which diagenesis becomes significant (e.g., Hower et al., 1979).

The type of curled morphology observed in the two deepest specimens has been attributed to sample desiccation in the SEM vacuum (Wilson and Pittman, 1977). However, because the samples in this study were freeze-dried and coated before placement in the SEM, we do not believe this curled morphology is an arti- fact of processing. Instead, we theorize that this curling is a consequence of removing interlayer water from smectite particles during the normal expulsion of fluids in late stages of consolidation.

Variations in mineralogy at Site 646 are less pronounced than those at Site 647 (Cremer et al., this volume). In addition, because the sediments at Site 646 tend to be coarser-grained (Srivastava, Arthur, et al., 1987), the mineralogy of the claysized fraction is expected to exert less of an influence. Consequently, there appears to be little agreement between mineralogy and microstructure at Site 646. A slight increase in the "fleeciness" of the components deeper in the hole is consistent with a general increase in smectite and a decrease in grain size with depth at the site (Cremer et el., this volume).

A lack of any significant variation in microstructure between lithologic Units I (hemipelagic origin) and II (drift deposit buildup; Srivastava, Arthur, et al., 1987) suggests that the role of depositional processes is unimportant at this site. Fabric of samples from a detrital carbonate turbidite layer and a crossbedded and cross-laminated region in Hole 646A (Table 1) also shows no prominent differences from microstructure in the remainder of Zone X (compare Figs. 8 and 12). A slight increase in preferred orientation and the presence of small F-F domains in the fabric of these two samples is consistent with the general increase in consolidation with depth and therefore cannot be conclusively attributed to depositional processes. 


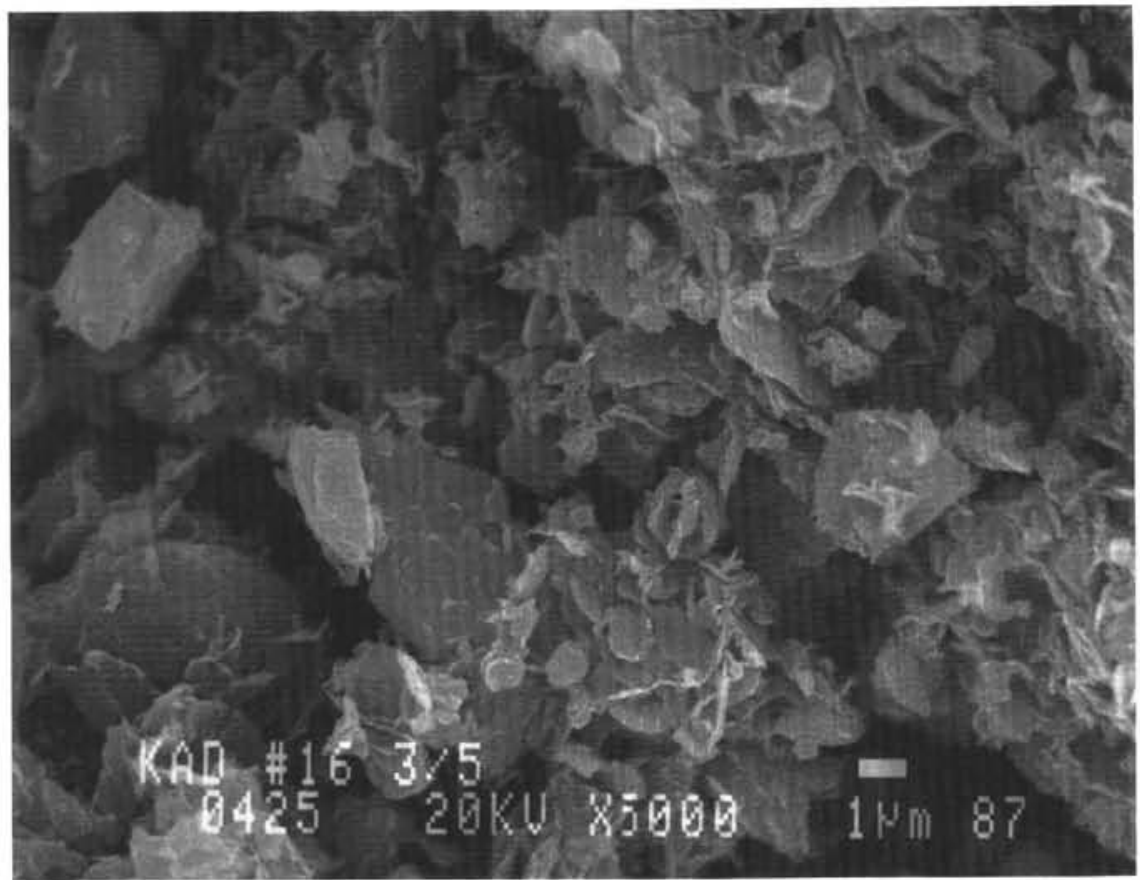

Figure 3. Sample 105-647B-8H-5, 71.2 mbsf; micrograph representative of Site 647 microstructure Zone A; fabric is characterized by silt-sized particles supported by a matrix dominated by clay-sized, well-defined plates, that display abundant E-E and E-F contacts.

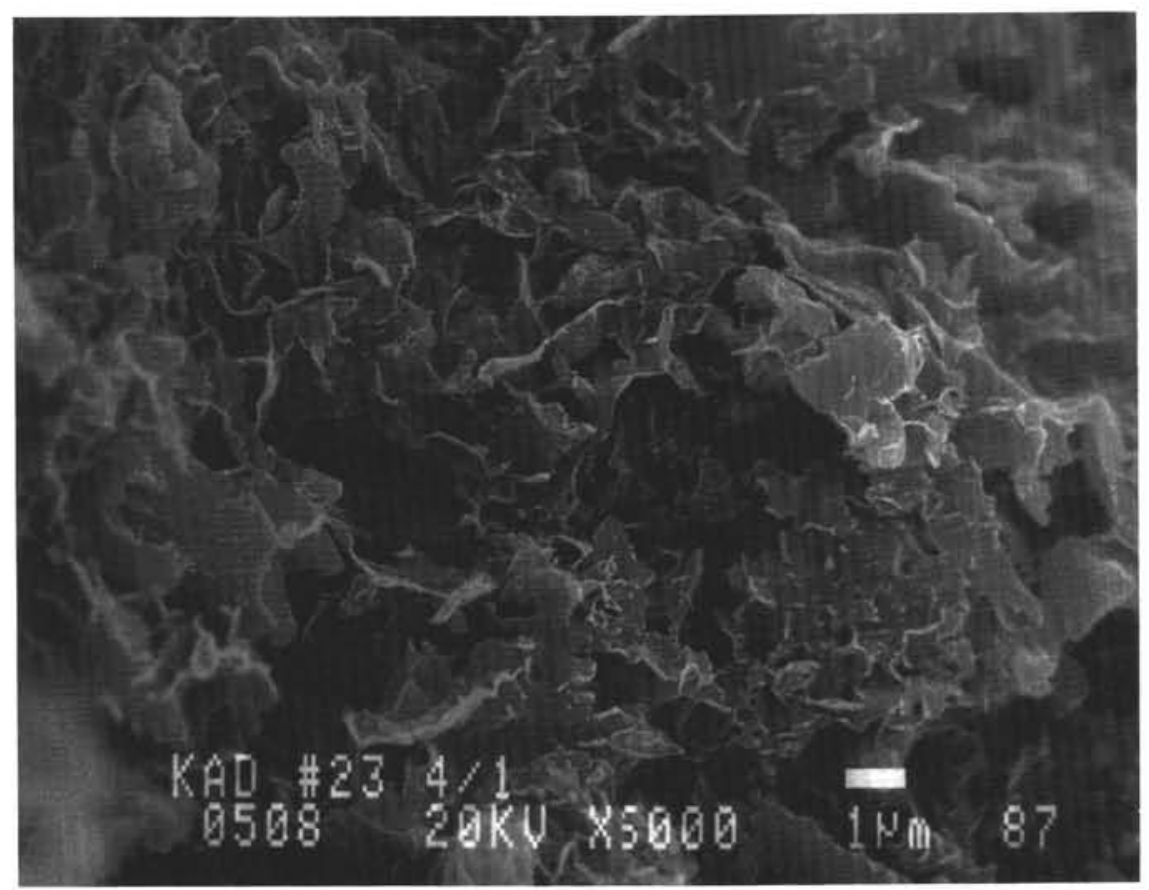

Figure 4. Sample 105-647A 25R-5, 238.9 mbsf; micrograph of fabric encountered in Site 647, Zone B. Fleecy, flaky particles are probably smectite. The majority of contacts are edge-toedge.

During consolidation, pore fluid is expelled, and porosity, void number, and size are reduced. The original E-E and E-F contacts break down, creating domains that have predominantly F-F contacts. These processes occur at both Sites 646 and 647, but their effect on microstructure is more apparent at Site 646 , where the competing influence of mineralogy is significantly less.

Because no obvious relationship was observed between depositional environment and sediment microstructure, the possible effects of other processes were considered. We investigated bio- 


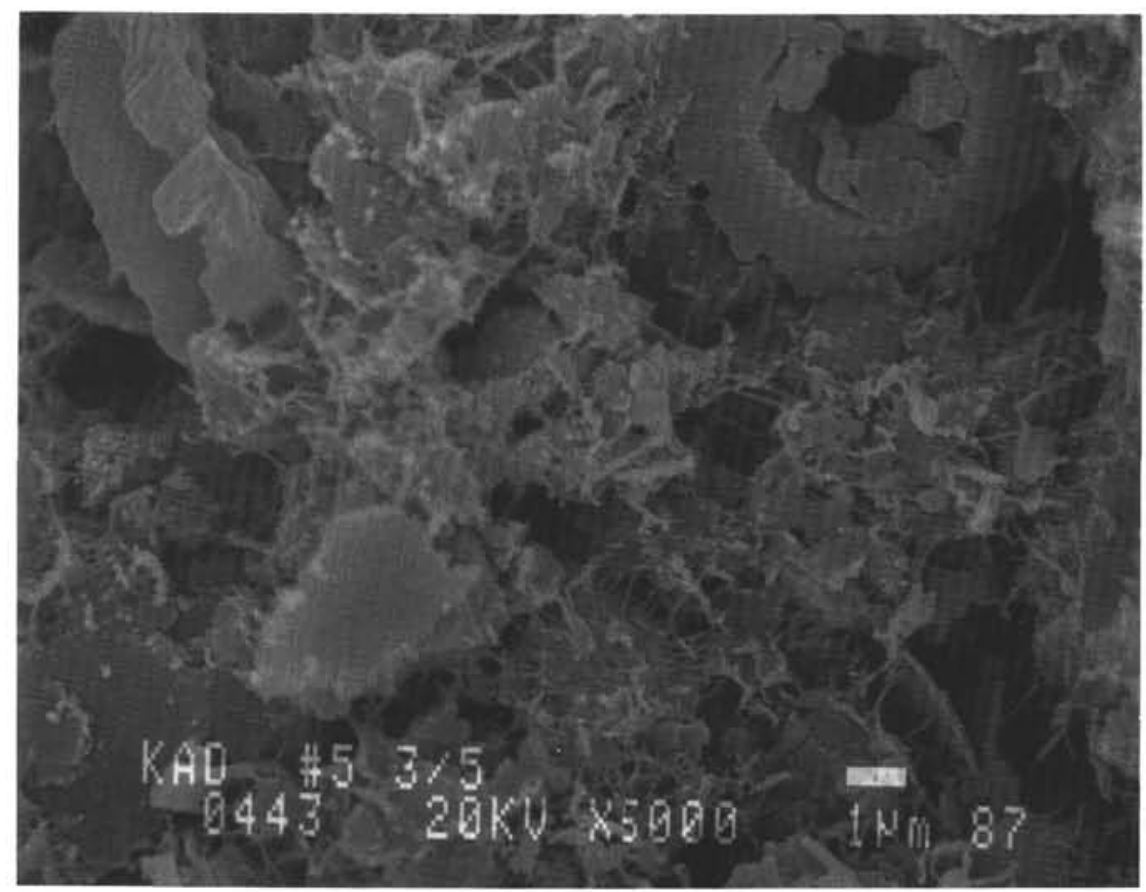

Figure 5. Sample 105-647A-15R-1, 136.4 mbsf; micrograph of Zone B that displays numerous examples of pore-bridging fibrous minerals.

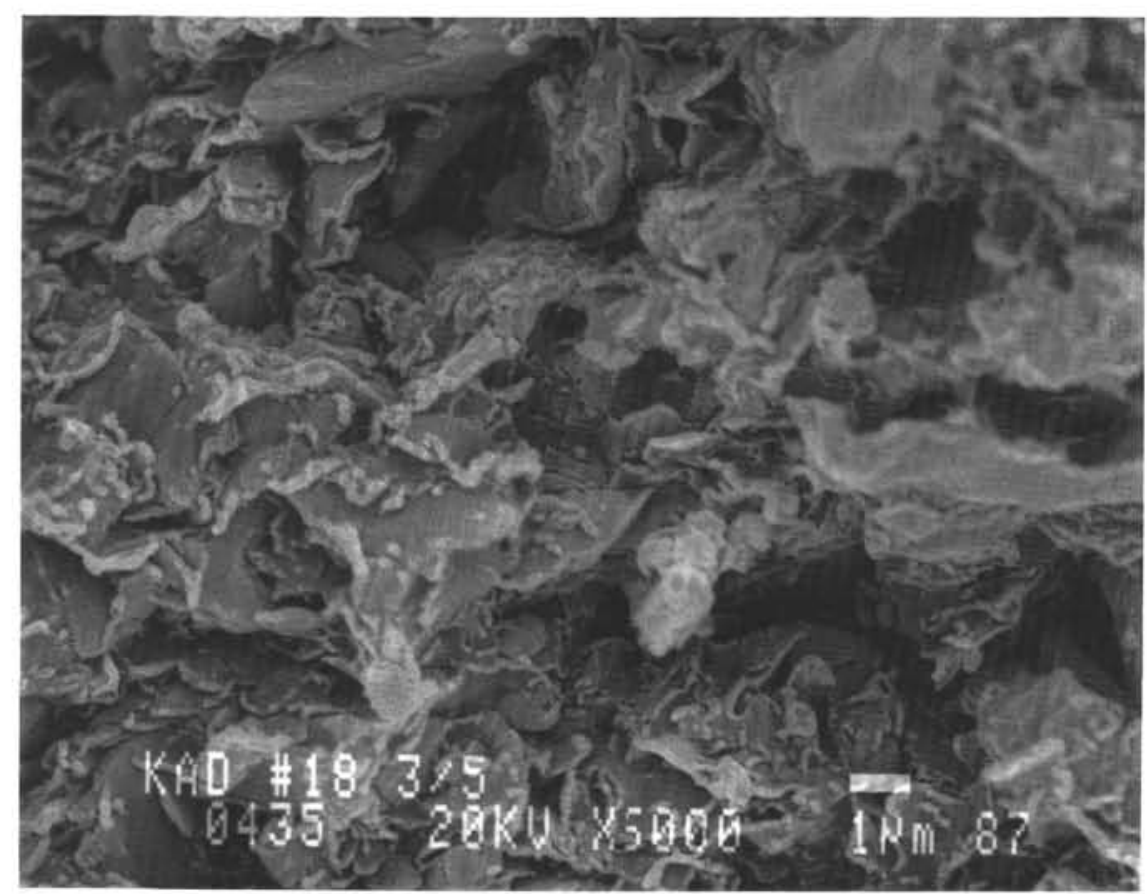

Figure 6. Sample 105-647A-62R-2, $599.8 \mathrm{mbsf}$; micrograph exemplifying fabric of deep samples in Zone $\mathrm{C}$ at Site 647 . Note the high degree of alignment of both particles and void spaces.

turbation and anthropogenic disturbances because of their frequent occurrence at these sites (Srivastava, Arthur, et al., 1987).

The effects of coring disturbance on sediment microstructure were investigated by examining several samples from Zone A of Hole 647B. These include a sample from $3.4 \mathrm{mbsf}$ and one from 95.3 mbsf. The former is reported to be in a zone "slightly" disturbed by coring; the latter is described as "moderately" dis- turbed (Srivastava, Arthur, et al., 1987). Both samples lie above regions affected by flow-in. No significant degree of bioturbation was reported for either sample. Both have similar textures, based on smear slide analyses (Srivastava, Arthur, et al., 1987).

Micrographs of representative fabric (Figs. 13 and 14) reveal surprises. Although the shallower sample experienced less severe disturbance, the resulting microstructure displays greater dis- 


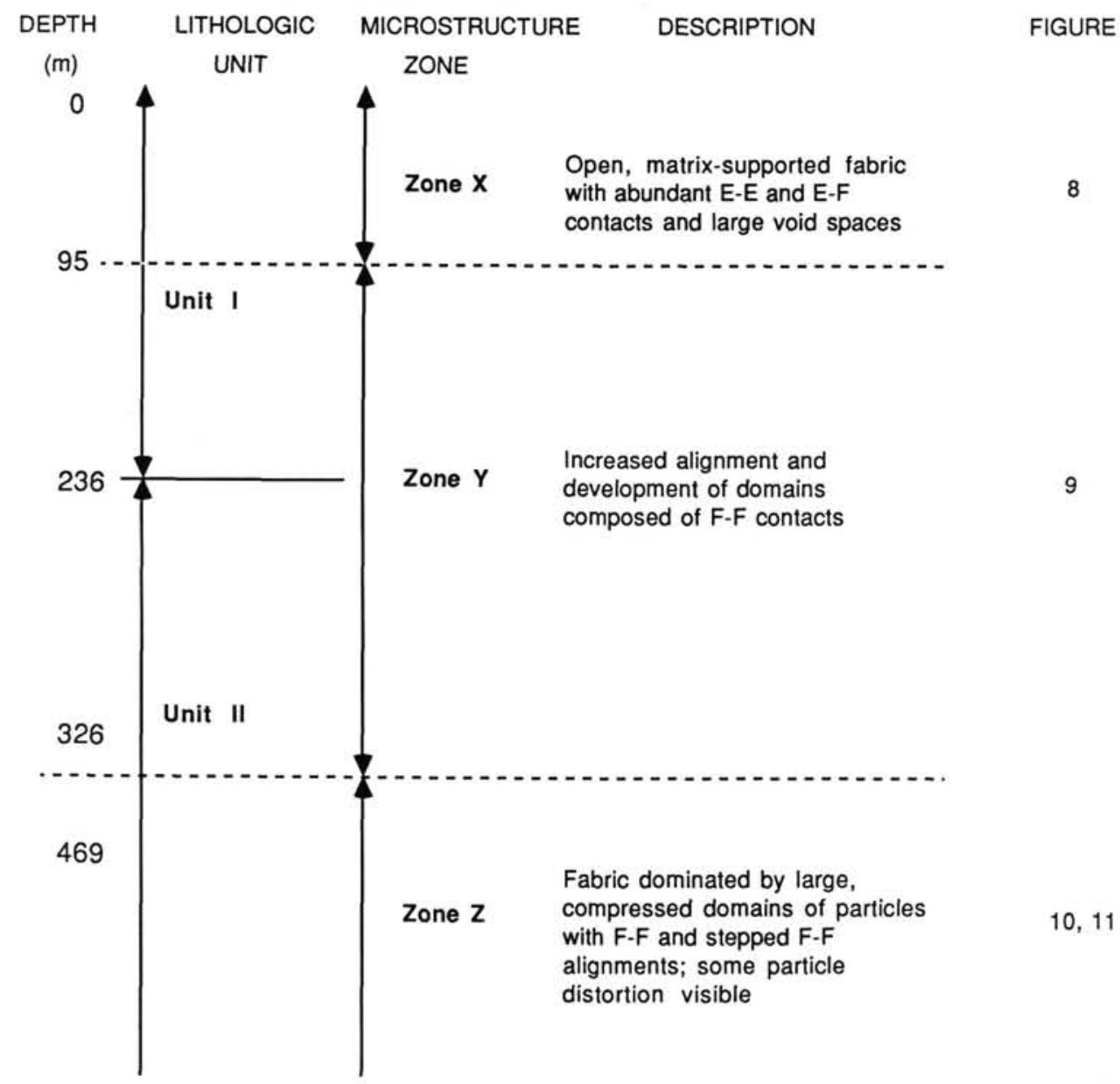

Figure 7. Site 646; microstructure zones and lithologic units.

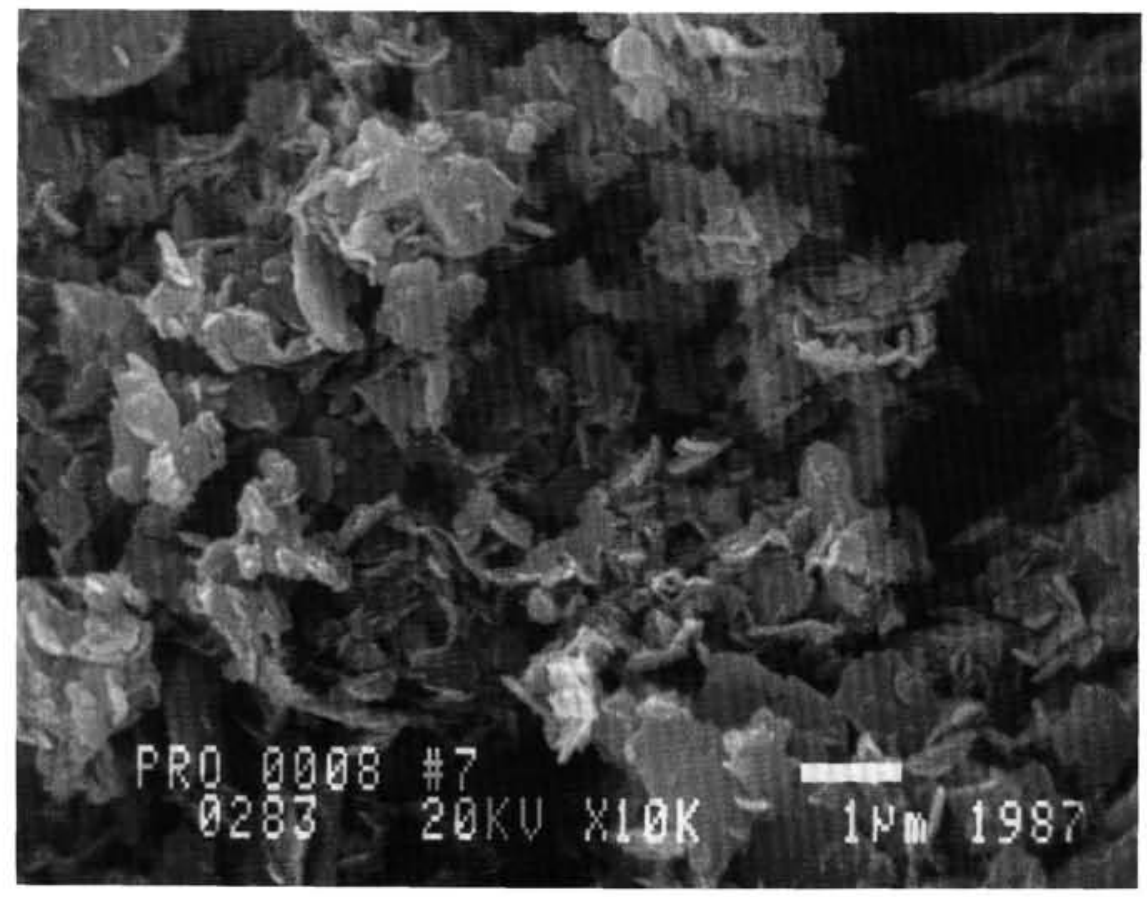

Figure 8. Sample 105-646A-1H-2, 2.3 mbsf; micrograph of fabric representative of Zone X at Site 646. Basically matrix-supported, numerous clay-sized plates having well-defined outlines are arranged primarily in single-particle arrangements. 


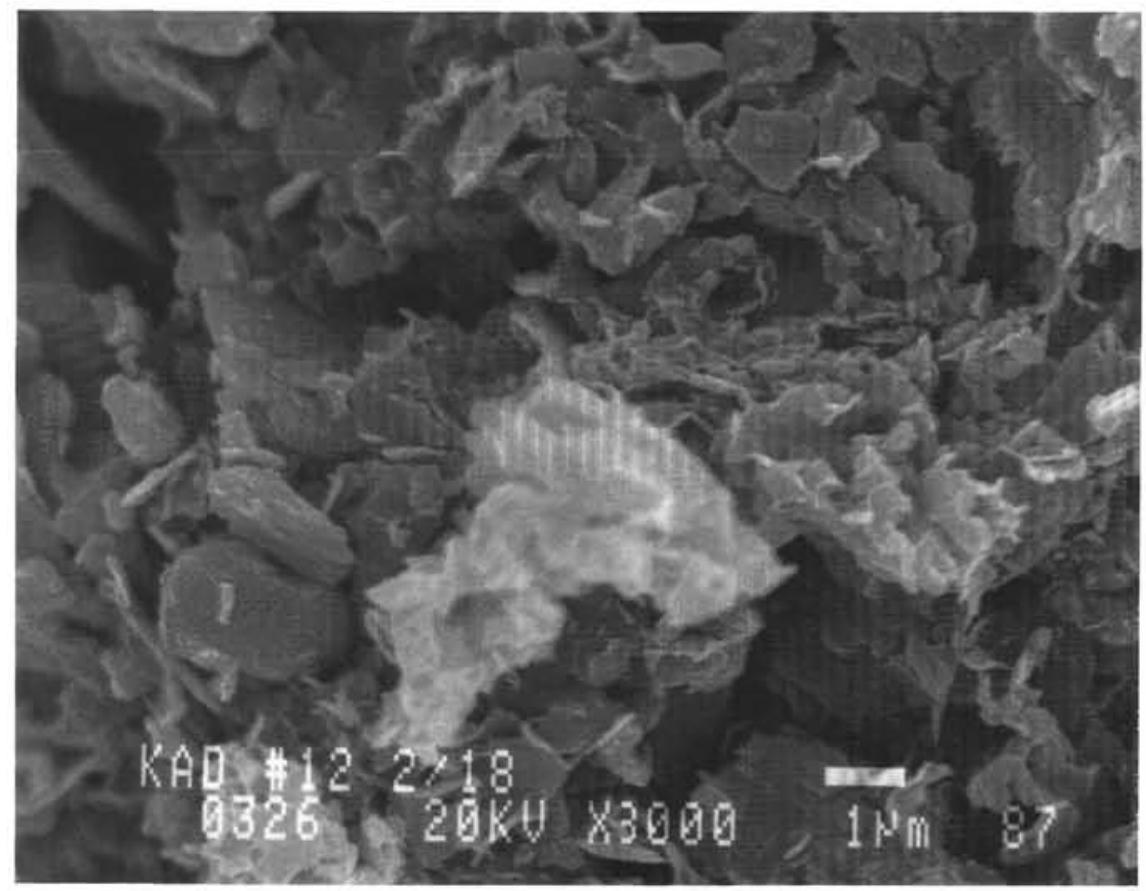

Figure 9. Sample 105-646B-26X-4, $241.4 \mathrm{mbsf}$; micrograph representative of transitional Zone $\mathrm{Y}$ at Site 646 . The fabric displays greater alignment and more numerous face-to-face contacts than the upper Zone X.

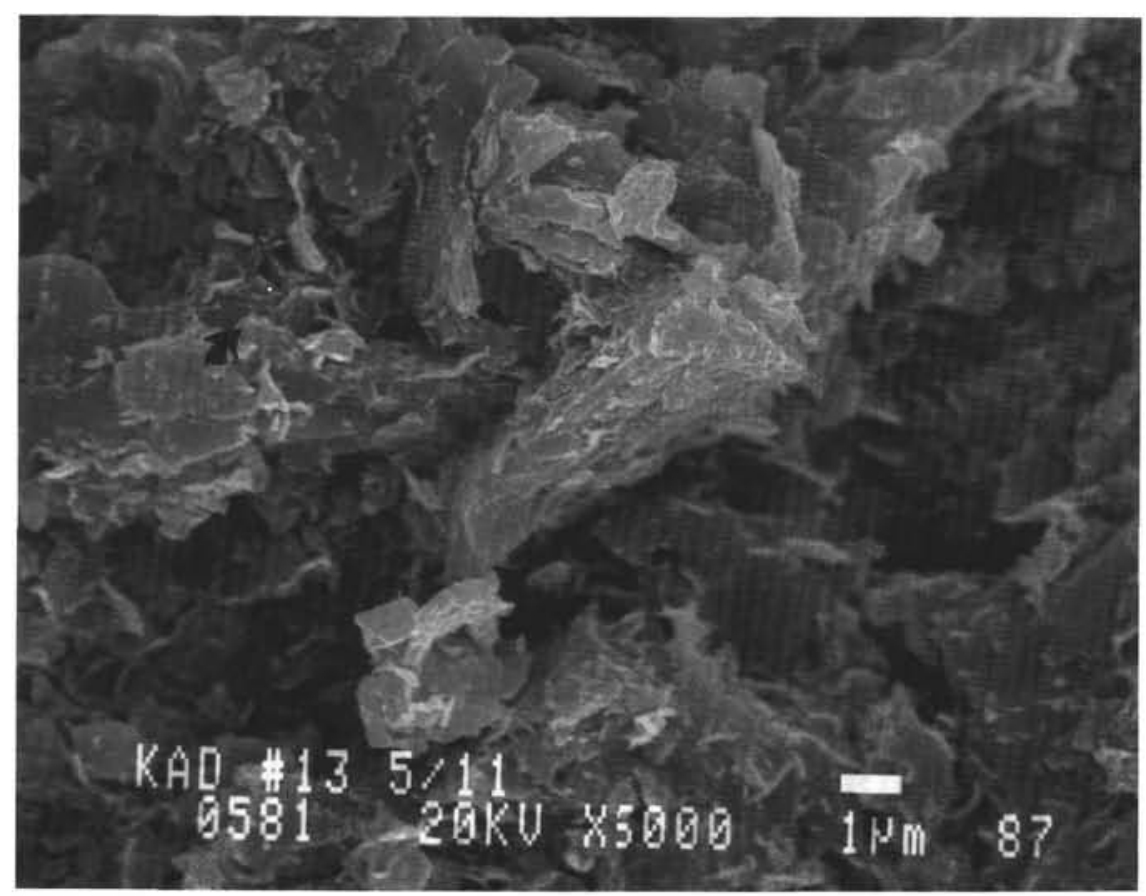

Figure 10. Sample 105-646B-72X-1, $680.1 \mathrm{mbsf}$; micrograph of fabric characteristic of deep layers of Site 646. Increased alignment of particles is particularly apparent in large domains like that in the center of the figure. Large numbers of particles are organized in F-F and stepped F$\mathrm{F}$ arrangements. Note the presence of relatively large, interconnected voids and areas of random particle orientation (marked by arrow). 


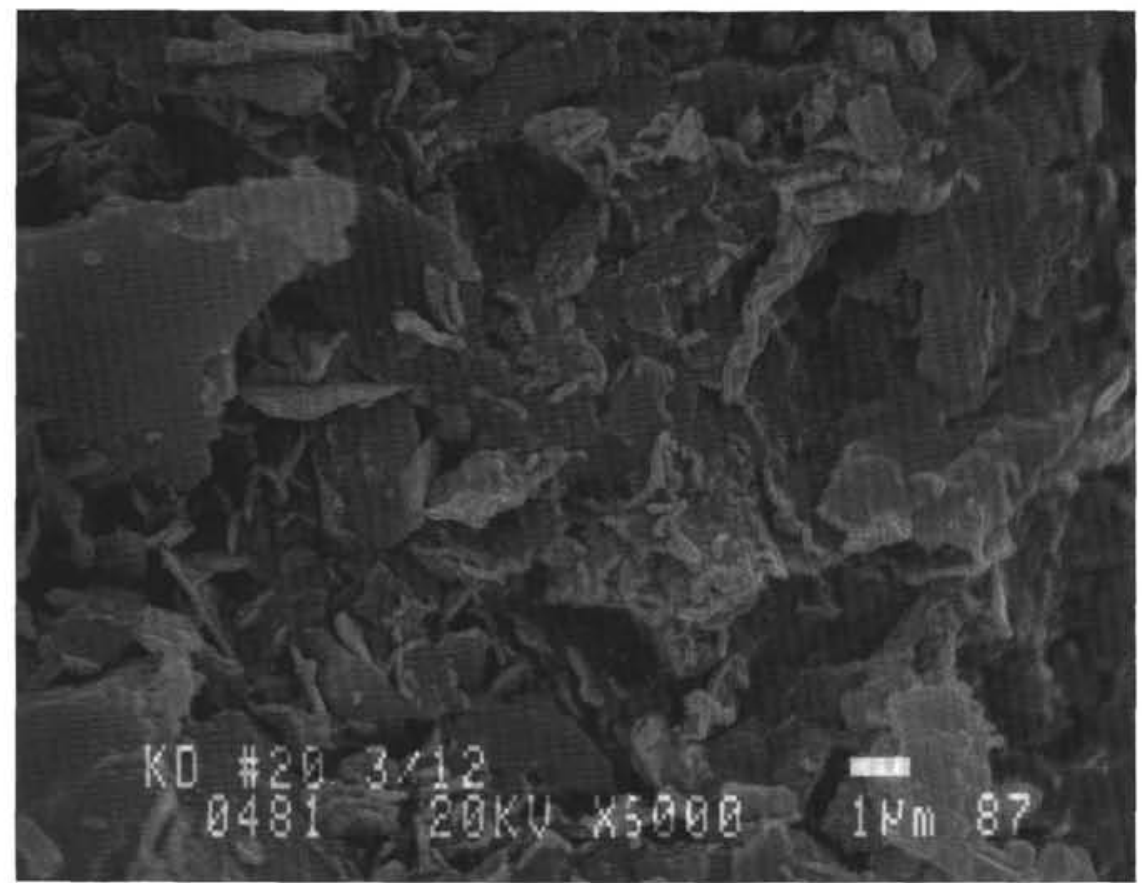

Figure 11. Sample 105-646B-50X-1, $469.5 \mathrm{mbsf}$; micrograph of a portion of Zone $\mathrm{Z}$ that contains compressed domains and particles that appear distorted.

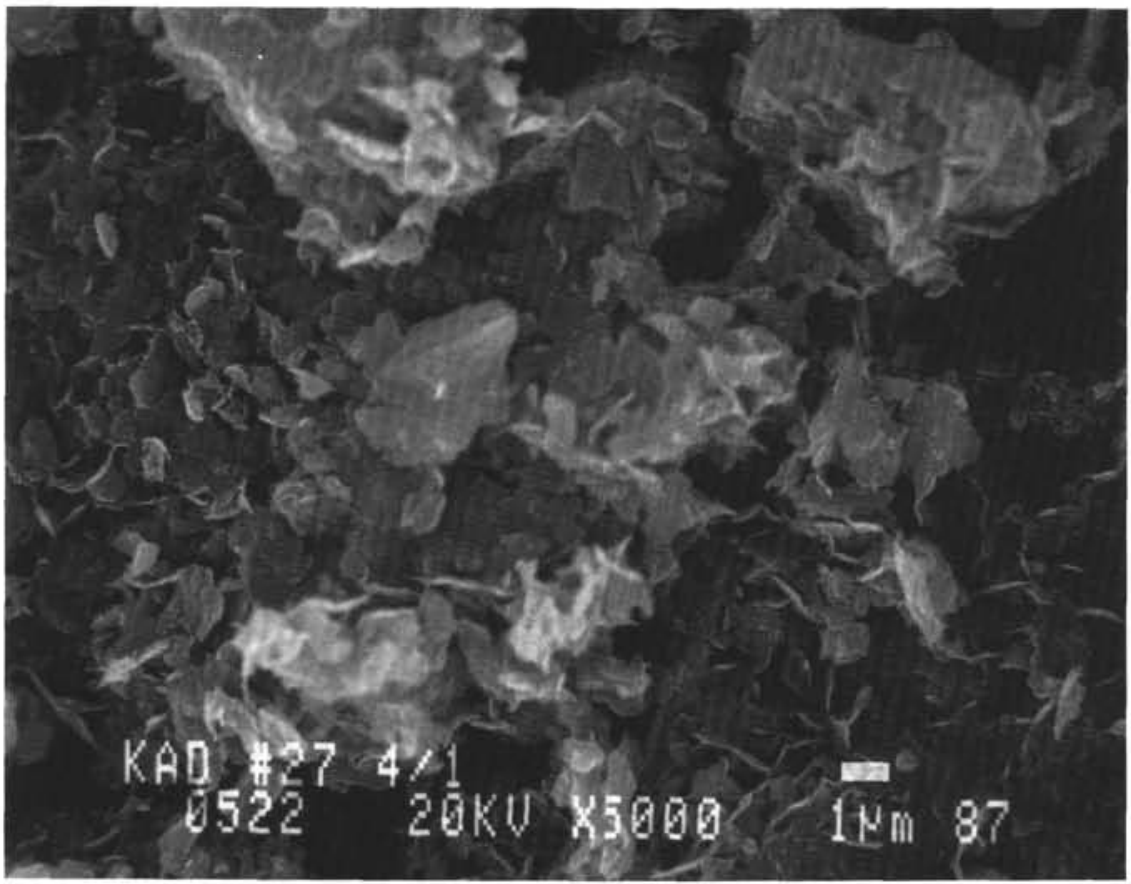

Figure 12. Sample 105-646A-10H-5, $91.2 \mathrm{mbsf}$; micrograph of sample from detrital carbonate turbidite layer. Fabric is characterized by open, random-particle configurations and numerous E-E and E-F contacts. No preferred alignment is visible.

ruption: a compressed fabric having numerous F-F contacts. The fabric of the deeper sample actually appears more open and has numerous E-E contacts. These results suggest that coring disturbance is most significant in sediments having high porosities and water contents.

The effects of extreme processes, such as complete remolding, on sediment microstructure were investigated as well. To ac- complish this, the sample at 162.9 mbsf in Hole 646B, which has a porosity of $67 \%$, was completely homogenized without adding or removing water and then was freeze dried and examined.

A few regions of strongly oriented domains that resemble the "swirl" pattern in the remolded Mississippi Delta sample discussed by Bennett et al. (1981) were observed. However, much 


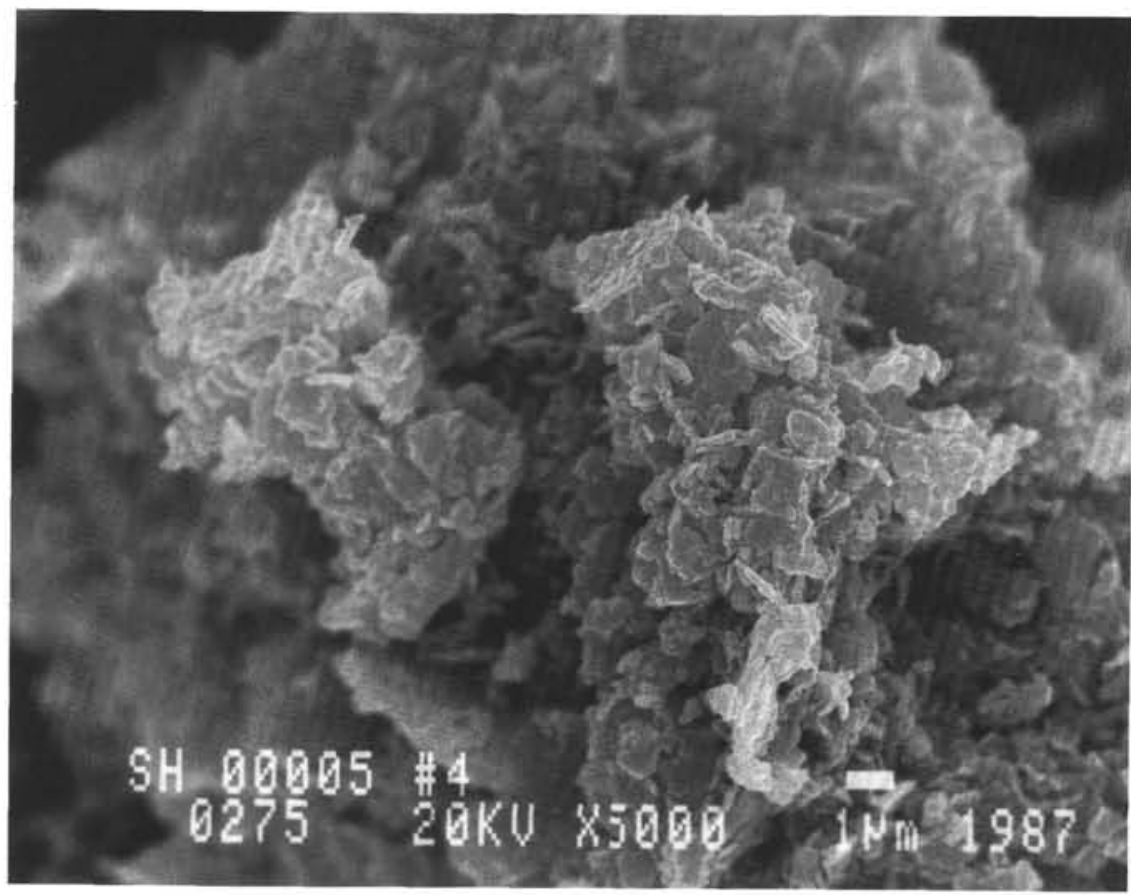

Figure 13. Sample 105-647B-1H-3, 3.4 mbsf; micrograph representative of fabric of shallow sample that had undergone "slight" coring disturbance. Despite a relatively high porosity $(72 \%)$, most regions of the sample contain compressed domains having large percentage of F-F contacts.

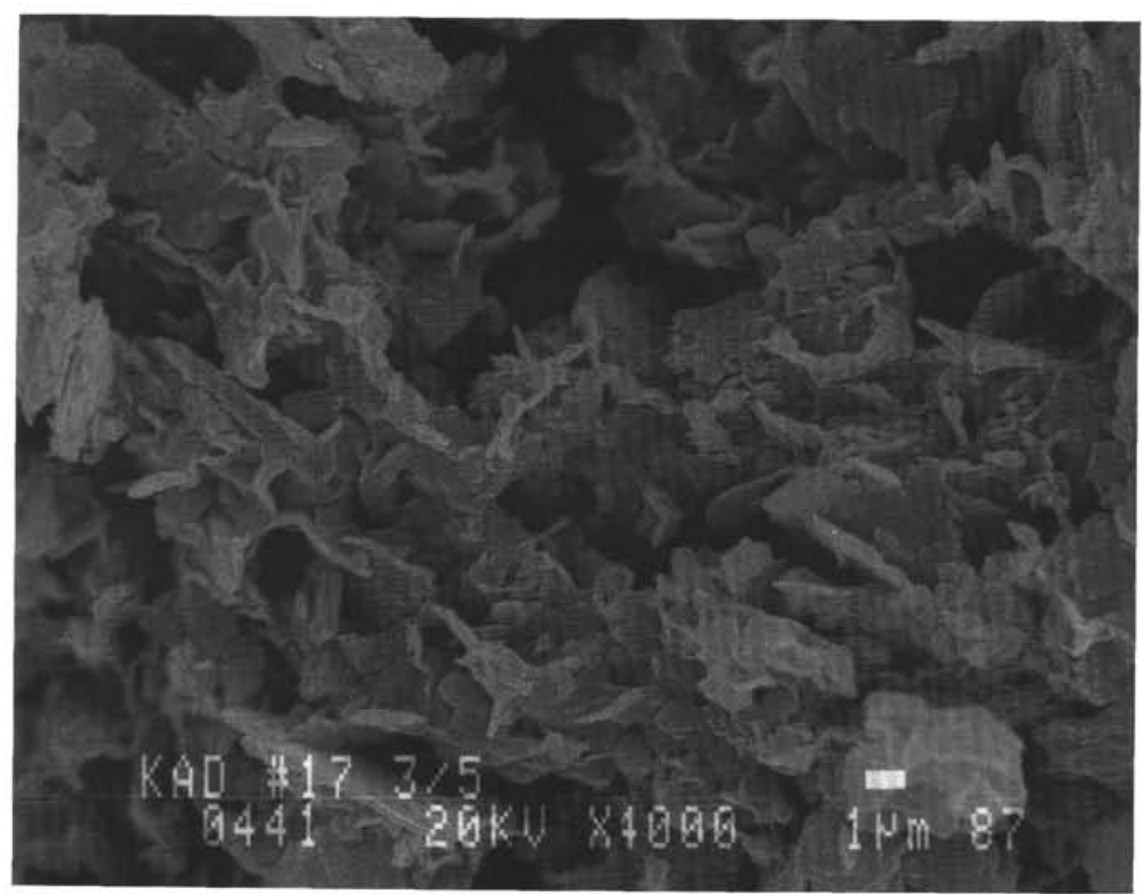

Figure 14. Sample 105-647B-11H-2, 95.3 mbsf; micrograph of sample "moderately" disturbed by coring. Numerous E-E contacts and single-plate chains are visible.

of the microstructure of the remolded sample displayed in Figure 15 remains open and random. In fact, the remolded fabric is similar to that of other samples from nearby depths in Hole 646B. Similar results were found by Torresan and Schwab (1987), who reported that remolding had little effect on the fabric of their samples from the Gulf of Alaska. In contrast, Bennett et al. (1981) reported that remolding completely destroyed the random fabric of two samples from the Mississippi Delta and equatorial Pacific.

A possible explanation for these differences lies in variations in the grain size of the samples studied. The sediments described by Torresan and Schwab (1987) more closely resemble 


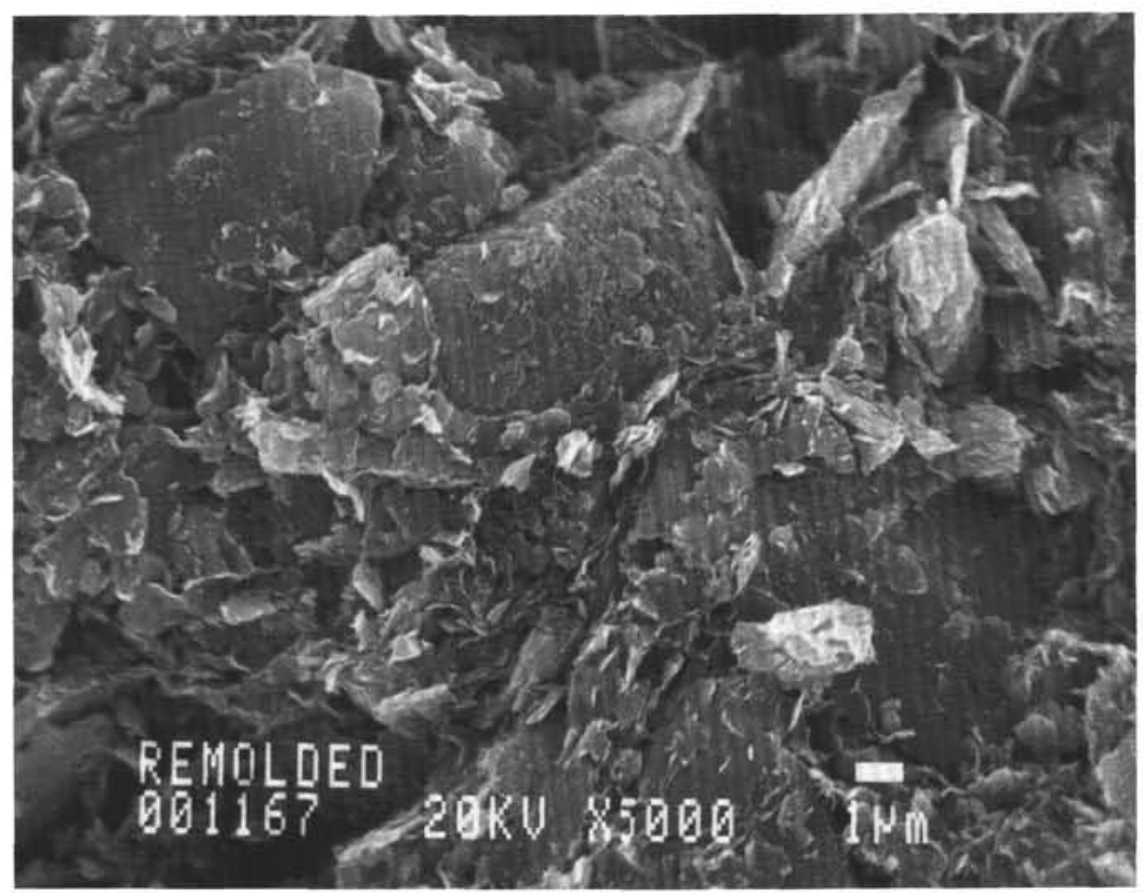

Figure 15. Sample 105-646B-18X-3, $162.9 \mathrm{mbsf}$; micrograph of remolded sample. Despite some regions of parallel particle alignment, much of the fabric remains open and random.

the Leg 105 deposits and are, in general, coarser-grained than the clays studied by Bennett et al. (1981). We theorize that the microstructure of fine-grained sediments may be more susceptible to disruption, partially because of their high porosity and relatively lower inherent strength.

Another post-depositional process that has been reported to have a strong and lasting effect on sediment microstructure is bioturbation. For example, O'Brien (1987) discovered striking differences between fabrics of claystones that had undergone bioturbation and those that had not. Nonbioturbated shales exhibit fabrics having a high degree of parallelism, while bioturbated samples display open, random microstructures. O'Brien (1987) reported that mucus coating produced by burrowing infauna binds particles so tightly that even lithification does not "significantly realign" bioturbated sediment fabric. Byers (1982), who also examined claystones, further stated that evidence exists that bioturbation "permanently randomizes" microstructure in fine-grained deposits.

A qualitative study of the effects of bioturbation on microstructure of Leg 105 sediments was undertaken. Six samples from lithologic Subunit IA (Site 646) displaying similar mineralogies (Cremer et al., this volume) and differing degrees of bioturbation (Srivastava, Arthur, et al., 1987) were examined (Table 2 ). The microstructures of these samples are remarkably similar. Compare, for example, Figures 16 and 17. The former is from an area described as $30 \%-60 \%$ bioturbated, the latter is from a layer displaying primary sedimentary structures (cross-lamination; Srivastava, Arthur, et al., 1987).

Although limited, these data suggest that despite the importance of bioturbation on a macroscale, its effects on a microscale may be less significant, at least in these sediments. Once again, we hypothesize that the sediment grain size exerts a strong influence on degree of disruption of the fabric by post-depositional processes. The previous studies cited concentrated on material that was finer-grained than that in most of the samples examined for this study (Srivastava, Arthur, et al., 1987).

These results and similar data on the effects of remolding lead us to theorize that coarser-grained sediments may be less likely
Table 2. Properties of selected samples from Hole 646A used in bioturbation study.

\begin{tabular}{|c|c|c|c|c|c|}
\hline \multirow[b]{2}{*}{ Sample } & \multirow{2}{*}{$\begin{array}{l}\text { Depth } \\
\text { (mbsf) }\end{array}$} & \multicolumn{3}{|c|}{ Texture $^{1}$} & \multirow[b]{2}{*}{ Degree of bioturbation ${ }^{2}$} \\
\hline & & $\mathrm{S}$ & $\mathrm{Si}$ & $\mathrm{Cl}$ & \\
\hline $2 \mathrm{H}-2$ & 7.4 & 5 & 85 & 10 & None reported. \\
\hline $3 \mathrm{H}-2$ & 19.1 & 10 & 25 & 65 & $30 \%-60 \%$ \\
\hline $8 \mathrm{H}-3$ & 69.1 & 5 & 90 & 5 & None reported. \\
\hline $9 \mathrm{H}-5$ & 81.0 & 5 & 55 & 40 & None reported. \\
\hline $10 \mathrm{H}-5$ & 91.2 & 1 & 70 & 29 & In detrital carbonate turbidite layer. \\
\hline $11 \mathrm{H}-3$ & 97.6 & 0 & 95 & 5 & In laminated region with cross-bedding. \\
\hline
\end{tabular}

${ }^{1} \mathrm{~S}=\%$ sand; $\mathrm{Si}=\%$ silt $; \mathrm{Cl}=\%$ clay. As reported on "barrel sheets" (based on smear slides) in Srivastava, Arthur, et al., 1987.

2 As described in "barrel sheets" in Srivastava, Arthur, et al., 1987.

to be affected by post-depositional processes. Contributing factors include smaller pore volume, relatively higher strength, and an inherently more stable particle configuration.

The one process that does seem to have a significant effect on the fabric in these Leg 105 deposits is the natural consolidation process, a result of increasing overburden stress. Shallow samples exhibit random, open fabrics having large voids and numerous EE and E-F contacts. Deeper, more consolidated samples display smaller, planar voids and strong orientation parallel to bedding.

The increase in preferred orientation with depth is in general agreement with the research of Faas and Crockett (1983), who examined DSDP Hole 515A in a sediment drift north of the Vema Channel. A notable difference exists between the fabric described here and that reported by Faas and Crocket, however. The downhole changes described by Faas and Crocket occur within approximately $100 \mathrm{~m}$ of the seafloor, at significantly shallower depths than those at Sites 646 and 647. Similarly, Bennett et al. (1981) reported a significant increase in fabric density and particle alignment at 120 mbsf in Mississippi Delta samples.

Two properties are believed to be responsible for the apparently anomalous open microstructure that persists to depths below 300 mbsf at Sites 646 and 647 . The shallow $(100-200 \mathrm{~m}) \mathrm{Leg}$ 


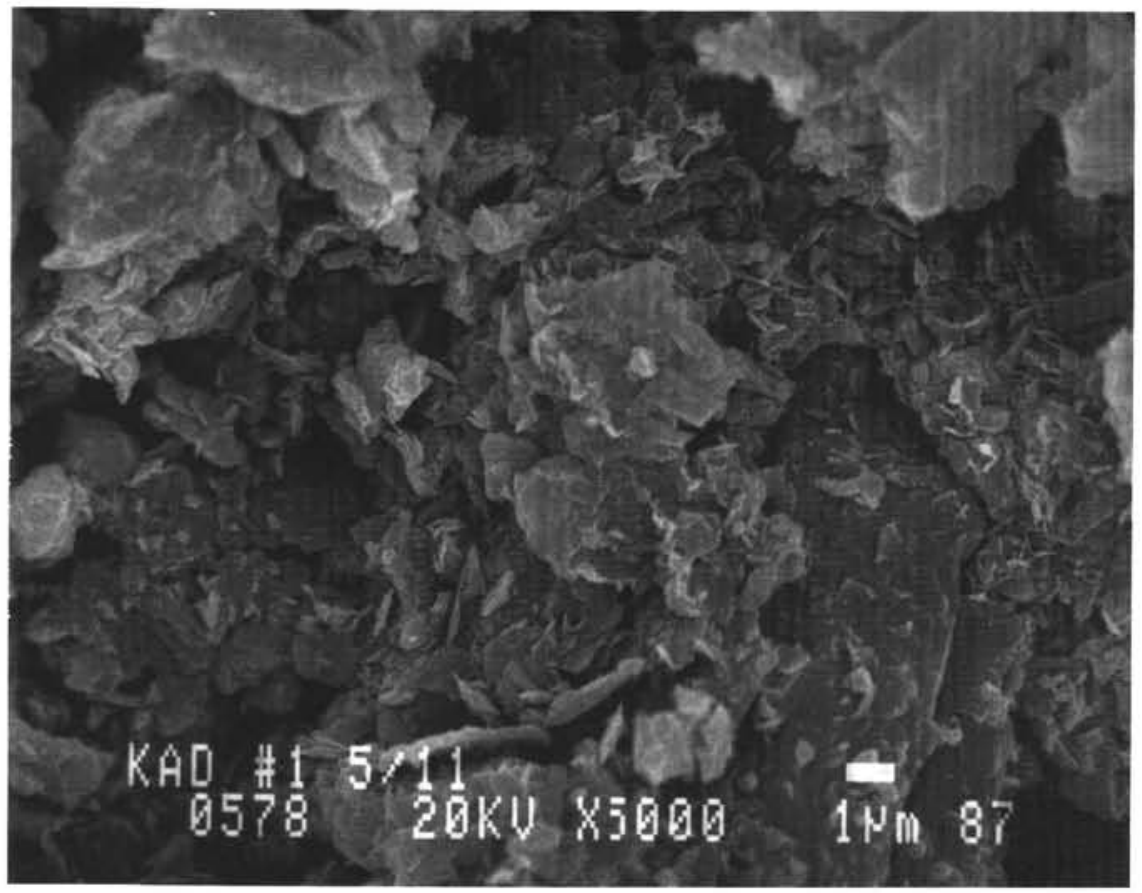

Figure 16. Sample 105-646A-3H-2, $19.1 \mathrm{mbsf}$; micrograph representative of fabric described as $30 \%-60 \%$ bioturbated. This microstructure is relatively open, but F-F contacts and compressed particle domains are common.

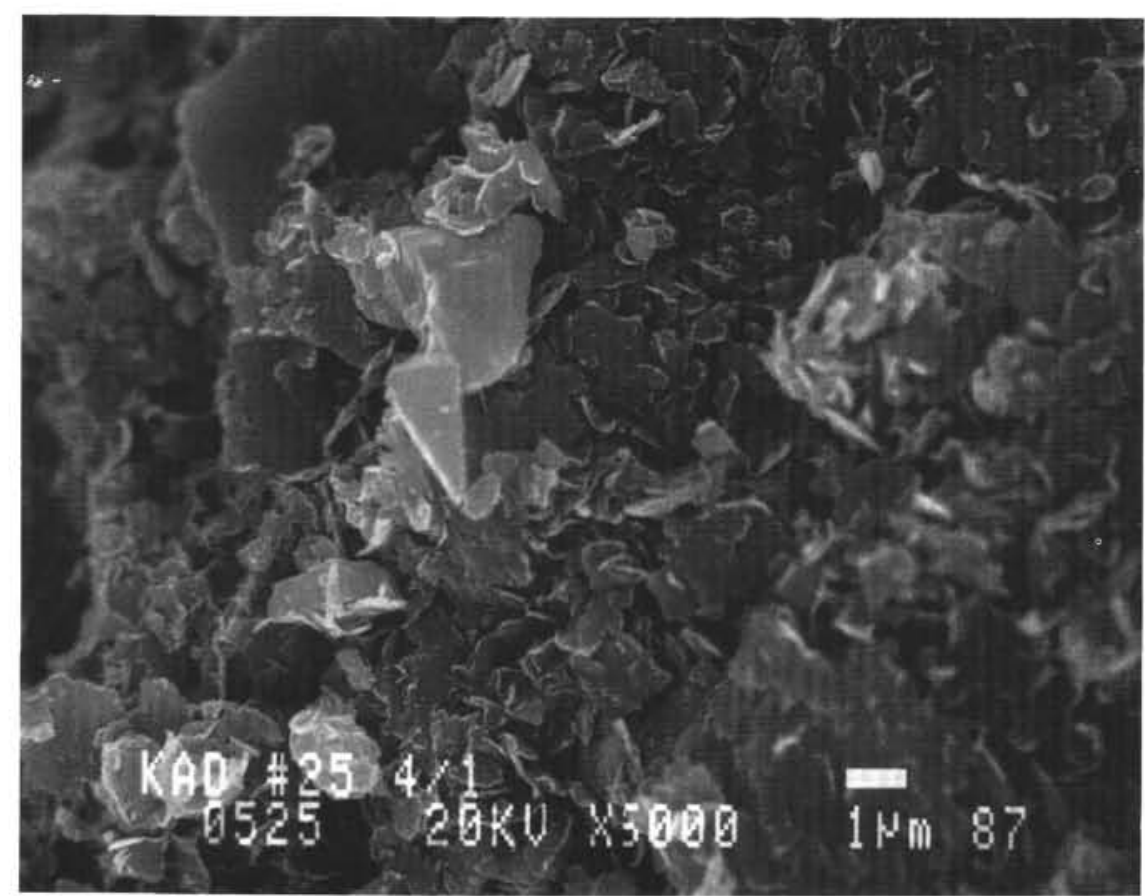

Figure 17. Sample 105-646A-11H-3, $97.6 \mathrm{mbsf}$; micrograph of sample from a layer displaying primary sedimentary structures (cross-lamination). The fabric is characterized by random particle arrangements, E-E contacts and single-plate chains.

105 sediments display extreme underconsolidation (Dadey and Silva, this volume). We hypothesize that underconsolidation exists deeper in these deposits, resulting in maintenance of comparatively high porosity sediments that exhibit microstructures more open and random than might be expected from the magnitude of the overburden stress.

In addition, the Leg 105 deposits are coarser-grained than those examined by Faas and Crocket (1983) and Bennett et al. 
(1981). Less consolidation, compression, and preferred orientation are expected in coarser-grained sediments (e.g., Lambe and Whitman, 1969).

\section{CONCLUSIONS}

Because of the stated purpose of this research, the main conclusion of this study is that microstructure is an inadequate diagnostic tool for identifying depositional environment, at least in the sediments studied. Depositional processes seem to have only an indirect effect at Site 647 , by transporting sediments of different mineralogies.

The influence of post-depositional processes also was investigated. Disturbance resulting from coring appears to be significant mainly in soft, high-porosity sediments. Evidence from studies of the effects of remolding (Bennett et al., 1981; Torresan and Schwab, 1987) suggests that grain size may be another important factor controlling the degree of disturbance. Coarse-grained fabrics do not seem to experience the severe disruption of finer-grained deposits.

Previous authors indicated that bioturbation has a significant and lasting effect on sediment microstructure (Byers, 1982; O'Brien, 1987). However, comparison of fabrics of samples from Hole 646A that exhibit differing degrees of bioturbation shows no consistent relationship between bioturbation and microstructure. Again, we theorize that the coarser grain size of the Leg 105 samples significantly reduces the influence of post-depositional bioturbation on fabric.

Consolidation appears to have the strongest effect on sediment microstructure in these holes. The decrease in void volume and water expulsion with increasing overburden stress is accompanied by development of F-F dominated domains, increased particle alignment, and smaller, more planar void spaces. Distortion of clay plates observed in very deep strata at each site is probably related to the expulsion of interlayer fluid from clay minerals.

\section{ACKNOWLEDGMENTS}

The assistance of scientists and technical staff on board the Resolution is gratefully acknowledged. Instruction and technical aid by G. Jolly helped make the research feasible. The manuscript benefited greatly from the comments and criticisms of H. Chamley, S. Srivastava, and one anonymous reviewer. Research was supported by NSF Grant No. TAMRF 76574.

\section{REFERENCES}

Bennett, R. H., Bryant, W. R., and Keller, G. H., 1977. Clay fabric and geotechnical properties of selected submarine sediment cores from the Mississippi Delta. NOAA Prof. Pap., 9:20-21.

Bennett, R. H., Bryant, W. R., and Keller, G. H., 1981. Clay fabric of selected submarine sediments: fundamental properties and models. J. Sediment. Petrol., 51:217-232.
Bohlke, B. M., and Bennett R. H., 1980. Mississippi Prodelta crusts: clay fabric and geotechnical analysis. Mar. Geotechnol., 4:55-82.

Byers, C. W., 1982. Geological significance of marine biogenic sedimentary structures. In McCall, P. L., and Tevesz, M. (Eds.), Animal-Sediment Relations: New York (Plenum Press), 221-256.

Chough, S. K., and Hesse, R., 1985. Contourites from Eirik Ridge, south of Greenland. Sediment. Geol. 41:185-199.

Dadey, K. A., 1983. Stress history of unlithified marine sediments in the Northwest Pacific [unpublished M.S. thesis]. University of Rhode Island, Kingston.

Faas, R. W., and Crocket, D. S., 1983. Clay fabric development in a deep-sea core: Site 515, Deep Sea Drilling Project Leg 72. In Barker, P. F., Carlson, R. L., et al., Init. Repts. DSDP, 72: Washington (U.S. Govt. Printing Office), 519-535.

Hower, J., Eslinger, E. V., Hower, M., and Perry, E. A., 1974. Mechanisms of burial metamorphism of argillaceous sediment: I. mineralogical and chemical evidence. Bull Geol. Soc. Am., 87:725-734.

Lambe, T. W., 1963. The Structure of Inorganic Soil: New York (Am. Soc. Civ. Eng.), Separate Paper No. 315.

Lambe, T. W., and Whitman, R. V., 1969. Soil Mechanics: New York (Wiley).

McCave, I. N., and Tucholke, B. E., 1986. Deep-current controlled sedimentation in the western North Atlantic. In Vogt, P. (Ed.), The Western North Atlantic Region: Boulder (Geol. Soc. Am.) 451-468.

O'Brien, N. R., 1987. The effects of bioturbation on the fabric of shale. J. Sed. Pet., 57:449-455.

Sangrey, D., 1977. Marine geotechnology-state of the art. Mar. Geotechnol., 2:45-80.

Shor, A. N., Kent, D. V., and Flood, R. D., 1984. Contourite or turbidite?: magnetic fabric of fine-grained Quaternary sediments, Nova Scotia continental rise. In Stow, D.A.V., and Piper, D.J.W. (Eds.), Fine Grained Sediments; Deep-Sea Processes and Facies: London (Geol. Soc. London Spec. Publ.), 15:253-275.

Srivastava, S., Arthur, M. A., et al., 1987. Proc. ODP, Init. Repts., 105: College Station, TX (Ocean Drilling Program).

Stow, D.A.V., and Piper, D.J.W., 1984. Deep-water fine-grained sediments: facies models. In Stow, D.A.V., and Piper, D.J.W. (Eds.) Fine-grained Sediments; Deep-Sea Processes and Facies: London (Geol. Soc. London Spec. Publ.) 15:611-646.

Torresan, M. E., and Schwab, W. C., 1987. Fabric and its relation to sedimentological and physical properties of near-surface sediment, Shelikog Strait and Alsek Prodelta. J. Sediment. Petrol., 57:408418.

Tovey, N. K., and Yan, W. K., 1973. The preparation of soils and other geological materials for the S.E.M. In Barden, L., and Pusch, R. (Eds.), Proc. Int. Symp. on Soil Structure: Stockholm (Swedish Society for Clay Res.), 59-65.

Wilson, M. D. and Pittman, E. D., 1977. Authigenic clays in sandstone: recognition and influence on reservoir properties and paleoenvironmental analysis. J. Sediment. Petrol., 47:3-31.

Date of initial receipt: 21 December 1987

Date of acceptance: 7 June 1988

Ms 105B-144 